\title{
Gene and protein expression profile of naive and osteo-chondrogenically differentiated rat bone marrow-derived mesenchymal progenitor cells
}

\author{
SUSANNE GRÄSSEL ${ }^{1}$, NAZISH AHMED ${ }^{2}$, CLAUDIA GÖTTL ${ }^{1}$ and JOACHIM GRIFKA ${ }^{3}$ \\ ${ }^{1}$ Experimental Orthopedics, Centre for Biotechnology, BioPark I, University of Regensburg, 93053 Regensburg, Germany; \\ ${ }^{2}$ Samuel Lunenfeld Research Institute, Mount Sinai Hospital, Toronto, Ontario, Canada; ${ }^{3}$ Department of \\ Orthopedics, University of Regensburg, Kaiser Karl V Allee 3, 93077 Bad Abbach, Germany
}

Received December 5, 2008; Accepted February 12, 2009

DOI: 10.3892/ijmm_00000188

\begin{abstract}
Adult mesenchymal progenitor cells (MPCs) are adherent stromal cells of non-haematopoietic origin derived from bone marrow and other tissues. Upon limited in vitro expansion, they retain their self-renewal capacity as well as their potential to differentiate into tissues of mesenchymal lineage, such as bone, cartilage, muscle, tendon and connective tissues. Amongst these tissues, cartilage is the only one with insufficient self-renewal capacity, thus MPCs would qualify as an excellent tool for therapeutic regeneration of focal cartilage lesions. However, optimal in vitro manipulation of MPCs is a prerequisite; identification and a better understanding of the molecular mechanisms regulating their differentiation pathways are needed. Despite wide usage of rats as a mammalian experimental model for preclinical fracture healing and orthopaedic tissue regeneration studies, basal gene and protein expression profiles of the osteo-chondrogenic differentiation lineages of adult rat MPCs have rarely been investigated. Therefore, this study was carried out for a quantitative RT-PCR based time-course profiling of osteo- and chondrogenesis related gene expression in undifferentiated and differentiated rat adult MPCs. In addition, with an antibody array analysis TIMP-1, MCP-1 and VEGF $\alpha$-164 were detected in the culture supernatant and CINC-2 and B-NGF in the cell
\end{abstract}

Correspondence to: Dr Susanne Grässel, Department of Orthopedic Surgery, Experimental Orthopedics, ZMB/BioPark 1, JosefEngertstrasse 9, 93053 Regensburg, Germany

E-mail: susanne.graessel@klinik.uni-regensburg.de

Abbreviations: MPCs, mesenchymal progenitor cells; TIMP, tissue inhibitor of matrix metalloproteases; MMP, matrix metalloproteases; VEGF, vascular endothelial growth factor; VEGFR, VEGF receptor; $\mathrm{MCP}$, monocyte chemoattractant protein; CINC, cytokine-induced neutrophil chemoattractant; NGF, nerve growth factor; Ihh, Indian hedgehog; TGF, transforming growth factor; COMP, cartilage oligomeric matrix protein; CNTF, ciliary neurotrophic factor; IFN, interferon; IL, interleukin; MIP, macrophage inflammatory protein

Key words: mesenchymal progenitor cells, rat, osteogenic, chondrogenic, profiling lysate of MPCs according to their differentiation commitment. Identification of differentially expressed genes and proteins along the osteo-chondrogenic lineage provides a foundation for a more reproducible and reliable quality and differentiation control of rat bone marrow-derived MPCs used for osteochondrogenic differentiation studies.

\section{Introduction}

Adult mesenchymal progenitor cells (MPCs) also known as mesenchymal stem cells (MSCs) are precursors of the tissues of mesenchymal lineage. These osteo-chondroprogenitor MPCs reside as part of the stroma in the medullary cavity of the bone (1) and make up $\sim 0.1 \%$ of the bone marrow cellular population which is otherwise dominated by haematopoietic cells. In vitro expansion of bone marrow cells leads to separation of the stromal MPCs based on their capacity of adherence to the plastic surface of tissue culture vessels. Upon limited expansion these cells retain not only their self-renewal capacity, but also their differentiation competence (2). This intrinsic competence is invoked under controlled nutritional and mechanical conditions to differentiate MPCs into bone, cartilage, muscle, tendon and connective tissue cells (3). MPCs have already shown promise for ex vivo regenerative medicine such as treatment of large bone defects $(1,4,5-7)$ and focal cartilage lesions (8-10).

Lack of precise molecular definition and common standards for initial cell preparations are major obstacles for MPC-based research and application. Nevertheless, genetic profiling of human MPCs for trans-differentiation capacities has shown differential gene expression according to origin and commitment status of MPCs (11). In contrast, very little is known about the genomic and proteomic profile of MPCs from other species which may qualify as osteo-chondroprogenitor cells. Mammalian animal models, like rat, share many aspects of the human genomic, cellular and immunological structures. Several inbred strains are available; parallel to the small size, rapid development of the animals and high experimental reproducibility are advantages of employing rat MPCs for in vitro studies. Rats are routinely used for fracture healing studies, which is a specialized post-natal repair process that recapitulates embryological skeletal development (12). Besides 
studies using genetically engineered MPCs to analyse their effects on healing critical sized fractures $(13,14)$, many reports exist which analyse factors affecting fracture healing and osteogenic differentiation of precursor cells residing in the callus during endochondral ossification in the rat model (15-18). Importantly, rats are additionally employed for osteogenic and chondrogenic differentiation studies of bone marrow derived or synovial MPCs (19-21). In order to elucidate molecular signalling pathways during fracture healing, a transcriptional profiling of temporal gene expression rates during callus maturation was performed in the rat model. Here, RNA was isolated from total callus tissue which contained a mixture of not well defined cells in various differentiation stages (22). However, genomic and proteomic profiling of rat CD45depleted MPCs during progression along the osteogenic/ chondrogenic differentiation pathway is either incomplete or unavailable.

Therefore, this study undertook mRNA level profiling of selected genes in undifferentiated adult rat MPCs defined as baseline gene expression profile. Changes in gene regulation were then evaluated in an in vitro time-course study during osteo-chondrogenic differentiation.

Additionally, a protein profile of selected growth factors and cytokines generated from undifferentiated MPCs was compared with that of cells which were differentiated along osteogenic and chondrogenic lineages.

Establishing a differential, temporal gene and protein expression profile allowed identification of markers suitable for monitoring progression of rat MPCs along the osteogenic and chondrogenic pathway. This knowledge is essential for providing proper and optimized conditions for in vitro differentiation studies of MPCs.

\section{Materials and methods}

Preparation of MPCs and cell culture. MPCs were isolated from rat bone marrow as described earlier (23). Briefly, bone marrow was removed from the tibiae and femora of 6-week old male Sprague-Dawley rats by centrifugation $(800 \mathrm{xg}$ for $3 \mathrm{~min}$ in an Eppendorf mini-centrifuge). Homogenized bone marrow was cultured in $175 \mathrm{~cm}^{2}$ tissue culture flasks in proliferation medium containing $5 \%$ glutamate, $1 \%$ antibiotics/antimycotics and $10 \%$ FBS (Gibco, Invitrogen, UK) in $\alpha$-MEM (Sigma Aldrich, Germany). Non-adherent cells were removed on the 3rd day and the adherent CFU-cells were proliferated until $70 \%$ confluency. Magnetic associated cell sorting procedure (MACS, Miltenyi Biotech, Germany) was carried out according to the manufacturer's instructions. In short, expanded cells from 3-5 different rats were incubated in suspension with $4 \mu 1$ of selected antibody $/ 10^{6}$ cells for $5 \mathrm{~min}$ at $37^{\circ} \mathrm{C}$ followed by washing and incubation with goat anti-mouse secondary antibody coupled with magnetic beads for $15 \mathrm{~min}$ at $4^{\circ} \mathrm{C}$. This suspension was passed through a magnetic column (Miltenyi Biotec's LS-MACS columns). While labelled cells were retained by the magnetic field, the flow through containing the unlabelled negative fraction was collected by washing the columns with buffer. After removing the column from the magnetic field, the antibody labelled cells (positive fraction) were also flushed out. For both fractions cells were counted and stained. Antibodies used for MACS were directed against rat CD45 (CBL 1502, Chemicon, Germany), rat CD49a (SM 805P, Acris, Germany), rat CD71 (\#554890) and rat CD106 (\#559165) (both BD Bioscience Pharmingen, USA). The CD45-negative, unlabelled fraction was used for further differentiation studies while the CD45-positive, labelled fraction was discarded.

Chondrogenic and osteogenic differentiation of MPCs. For chondrogenesis, cells were cultured for up to 21 days in high density 3-D alginate bead cultures. To prepare the culture $10^{7}$ cells $/ \mathrm{ml}$ were suspended in $1.2 \%$ alginate. The cell-alginate amalgam was dropped into $102 \mathrm{mM} \mathrm{CaCl}_{2}$ solution via a syringe which resulted in a formation of beads with a diameter of 2-3 mm containing $\sim 10^{5}$ cells $/$ bead. Beads were cultured in $2.3 \mathrm{ml}$ chondrogenic medium in 12-well tissue culture plates. Ten alginate beads per culture set up were used for RNA isolation and gene expression analysis. Cells were released from alginate by incubation at $37^{\circ} \mathrm{C}$ for $30 \mathrm{~min}$ in $55 \mathrm{mM}$ sodium citrate and $0.15 \mathrm{M}$ sodium chloride buffer followed by cell recovery with a $3 \mathrm{~min}$ spin at $750 \mathrm{x} \mathrm{g}$. Chondrogenic medium contained, ITS+ premix $6.25 \mu \mathrm{g} / \mathrm{ml}$ insulin, $6.25 \mathrm{ng} / \mathrm{ml}$ selenium acid, $6.25 \mu \mathrm{g} / \mathrm{ml}$ transferrin, $1.25 \mathrm{mg} / \mathrm{ml} \mathrm{BSA}$ and $5.35 \mu \mathrm{g} / \mathrm{ml}$ linoleic acid (BD Biosciences), $110 \mu \mathrm{g} / \mathrm{ml}$ pyruvate, $40 \mu \mathrm{g} / \mathrm{ml}$ proline, $0.1 \mu \mathrm{M}$ dexamethasone, $50 \mu \mathrm{g} / \mathrm{ml}$ ascorbic acid and $10 \mathrm{ng} / \mathrm{ml}$ TGFß-3 (24) (R\&D Systems) in $\alpha$-MEM high glucose medium (Gibco, Invitrogen). Alginate sodium salts were acquired from Sigma Aldrich. For osteogenesis, $2.5 \times 10^{5}$ cells/well were cultured for up to 21 days in 6-well culture plates as monolayer in osteogenic medium containing $10 \%$ FCS, $1 \%$ pen/strep, $10 \mathrm{nM}$ dexamethasone, $50 \mu \mathrm{g} / \mathrm{ml}$ ascorbate $2-\mathrm{PO}_{4}$ and $10 \mathrm{mM} \mathrm{B-Na-}$ glycerophosphate (Sigma Aldrich) in $\alpha$-MEM high glucose medium.

Immunofluorescence. For immunofluorescence analysis, alginate beads were irreversibly polymerized by replacing $\mathrm{CaCl}_{2}$ with $100 \mathrm{mM} \mathrm{BaCl}{ }_{2}$ (25). The beads were fixed with $4 \%$ paraformaldehyde and after sequential dehydration embedded in paraffin. Sections $(4 \mu \mathrm{m})$ were acquired and the deparaffinized and rehydrated sections were used for staining after hyaluronidase digestion for $6 \mathrm{~min}$ at RT. Undifferentiated MPCs kept in monolayer culture were fixed with $4 \%$ paraformaldehyde. Slides were blocked for $1 \mathrm{~h}$ at $37^{\circ} \mathrm{C}$ in $5 \%$ normal goat serum and 1\% BSA in PBS containing Complete Mini 1:5 protease inhibitor solution (Roche, Germany). After washing with PBS, cells were stained overnight at $4^{\circ} \mathrm{C}$ with monoclonal antibodies which recognize rat collagen II, diluted 1:100, and rat D7fib, diluted 1:50 (both from Acris) and CD49a, diluted 1:50 (Chemicon). The appropriate Alexa 568 or 488 conjugated secondary antibodies (goat anti-mouse, $5 \mu \mathrm{g} / \mathrm{ml}$, Molecular Probes, USA) were added for $1 \mathrm{~h}$ at RT. After washing, slides were permanently mounted with fluorescent mounting medium (Dako, USA) and covered with cover slips. Slides were evaluated with a scanning laser microscope (C1 confocal microscope from Nikon, Germany) and photos were taken with a Nikon $\mathrm{C} 4$ camera and software.

Histological analysis. Osteogenically differentiated cells were washed with PBS and fixed with methanol for $10 \mathrm{~min}$. After rinsing with water, staining was carried out for 2 min with $1 \%$ 
Table I. Primers used for quantitative RT-PCR.

\begin{tabular}{|c|c|c|c|c|}
\hline Gene & $\begin{array}{c}\text { NIH } \\
\text { accession no. }\end{array}$ & $\begin{array}{l}\text { Amplicon } \\
\text { (bp) }\end{array}$ & $\begin{array}{l}\text { Forward primer } \\
\qquad\left(5^{\prime}-3^{\prime}\right)\end{array}$ & $\begin{array}{l}\text { Reverse primer } \\
\qquad\left(5^{\prime}-3^{\prime}\right)\end{array}$ \\
\hline$\alpha 10$ & XM_001063132 & 188 & -tttcttcgggaaatcagagc & -tggatggagaagccaatctc \\
\hline$\alpha 11$ & XM_001075650 & 170 & -tggaggtccaacacttcctc & -gggtttcagtccctcctctc \\
\hline Aggrecan & NM_022190 & 224 & -ggccttccctctggatttag & -ccgcactactgtccaac \\
\hline B-Actin & NM_031144 & 104 & -gtagccatccaggctgtgtt & -ccctcatagatgggcagagt \\
\hline CINC-2 & D87926 & 287 & -cactgcttctgctgcttctg & -tgacttctgtctgggtgcag \\
\hline Colla1 & RGD61817* & 59 & -tccagggctccaacgaga & -ctgtaggtgaatccactgttgc \\
\hline Col2a1 & NM_012929 & 60 & -cccetgcagtacatgcgg & -ctcgacgtcatgctgtctcaag \\
\hline Col10a1 & AJ131848* & 247 & -ccctattggaccaccaggta & -tctctgtccgctctttgtga \\
\hline Col16a1 & M92642 & 97 & -gcctggtaccaaaggtgaaa & -catagcctggaggaccttga \\
\hline COMP & NM_012834 & 167 & -tgacttcgatgctgacaagg & -gaacgatctccattccetga \\
\hline Ihh & XM_343590 & 103 & -atgaagacggccatcactcag & -cgcgccagtagtccgtacttat \\
\hline MCP-1 & M57441 & 167 & -atgcagttaatgccccactc & -ttccttattggggtcagcac \\
\hline MMP-2 & NM_031054 & 111 & -gaccggtttatttggcgga & -ggcctcatacacagcgtcaat \\
\hline MMP-13 & XM_343345 & 93 & -acctgggatttccaaaagagg & -acacgtccttccctgagaaga \\
\hline ß-NGF & XM_001067130 & 182 & -ggacgcagctttctatcctg & -ctgtgtcaagggaatgctga \\
\hline Runx2 & XM_34016 & 86 & -gccgggaatgatgagaacta & -agatcgttcaacctggccact \\
\hline Sox 4 & XM_344594 & 58 & -ggcccatgaacgcctttat & -ctggatgaacgggatcttgtc \\
\hline Sox6 & XM_215016 & 51 & -gaaatccatgtccaaccaggac & -cgggcctgctcttcatagtaag \\
\hline Sox 9 & XM_343981 & 140 & -ctgaagggctacgactggac & -tactggtctgccagcttcct \\
\hline Tbox 2 & XM_220810 & 71 & -gcccactctccgtttgtatgag & -aggacgaggcatcggattc \\
\hline TIMP-1 & NM_053819 & 136 & -gattcgacgctgtgggaaat & -tttccgttccttaaacggcc \\
\hline TIMP-2 & NM_021989 & 140 & -ggcaagatgcacattaccctct & -atgtagcatgggatcatagggc \\
\hline TGFß-3 & NM_013174 & 86 & -ttccttcttggecgtatttcc & -tgtgtgggatccagaatcca \\
\hline VEGF $\alpha$ & NM_031836 & 71 & -tggctttactgctgtacctcca & -tttctgetcccettctgtcgt \\
\hline VEGFR-2 & NM_013062 & 95 & -ttgcctagtcaagcagctcgt & -cgatggtctcaccaatggttg \\
\hline
\end{tabular}

*Locus ID.

alizarin red prepared in $25 \%$ ammonia. Stained cells were thoroughly washed and photographed with a Nikon $\mathrm{C} 4$ camera after complete drying.

RNA isolation and reverse transcription. RNA was isolated by an affinity column chromatography method with Ambion's RNAqueous4-PCR kit according to the manufacturer's protocol. For removal of putative DNA contamination DNaseI enzyme (DNA-free, Ambion, USA) was used. RNA concentration was determined at a $585 \mathrm{~nm}$ wavelength with RiboGreen RNA quantification kit (Molecular Probes). RNA (0.5-1 $\mu \mathrm{g})$ was converted to cDNA with SuperScript II reverse transcriptase kit (Invitrogen) in $20 \mu 1$ of total reaction volume in the presence of 40 units $/ \mu 1$ recombinant ribonuclease inhibitor (RNase $\mathrm{OUT}^{\circledR}$ ), $500 \mu \mathrm{g} / \mathrm{ml}$ of Oligo-dT primers, $10 \mathrm{mM}$ dNTPs and 200 units of SuperScriptII enzyme in First-Strand Buffer and $0.1 \mathrm{M}$ DTT for $50 \mathrm{~min}$ at $42^{\circ} \mathrm{C}$ followed by an extension period of $15 \mathrm{~min}$ at $70^{\circ} \mathrm{C}$.

Relative quantitative PCR. Relative quantitative PCR was performed using the SYBR Green Dye I on ABI 7000 Prism Sequence detection system (AB Systems, USA) according to the manufacturer's instructions. Briefly, $1 \mu \mathrm{l}$ of cDNA was amplified in triplicates in $50 \mu \mathrm{l}$ final volume containing $0.2 \mu \mathrm{M}$ of each primer suspended in SYBR Green master mix (AB
Systems). Amplification parameters were identical for all primer pairs and were repeated for 40 cycles, denaturation occurred at $95^{\circ} \mathrm{C}$ for $0.15 \mathrm{~min}$ and annealing at $60^{\circ} \mathrm{C}$ for $1 \mathrm{~min}$. Mean relative quantification (RQ) values were calculated by the software 'RQ study application v1.1' (ABI Prism 7000 SDS software v1.1) according to the $\Delta \Delta \mathrm{Ct}$ method using $\beta$-actin as endogenous control and undifferentiated MPCs (day 0) as calibrator. Primers were designed either with freeware Primer3 (http://frodo.wi.mit.edu/cgi-bin/primer3/primer3_www.cgi) or 'Primer Express' software supplied by AB Systems. All primers were manufactured at MWG-Biotech, Germany and are listed in Table I. Prior to gene expression analysis, primer efficiency was determined with $10^{(1-S)}-1$, where $S$ is the slope of the curve of a cycle threshold $(\mathrm{Ct})$ standard curve. Only 90-100\% efficient primers were used for analysis (26) and efficiency was included into calculation of gene expression changes according to the method of Pfaffl et al (27). For each primer pair cDNA (not pooled) from 4-7 rats was used for PCR.

Antibody array analysis. RayBio ${ }^{\mathrm{TM}}$ (Tebu-bio, France) rat cytokine antibody array I was used according to the manufacturer's instructions. Briefly, membranes were blocked for $30 \mathrm{~min}$ in $5 \% \mathrm{BSA}$ in $0.01 \mathrm{M}$ Tris buffer with $0.15 \mathrm{M}$ $\mathrm{NaCl}$ (pH 7.6) followed by overnight incubation at $4^{\circ} \mathrm{C}$ in $1 \mathrm{ml}$ 


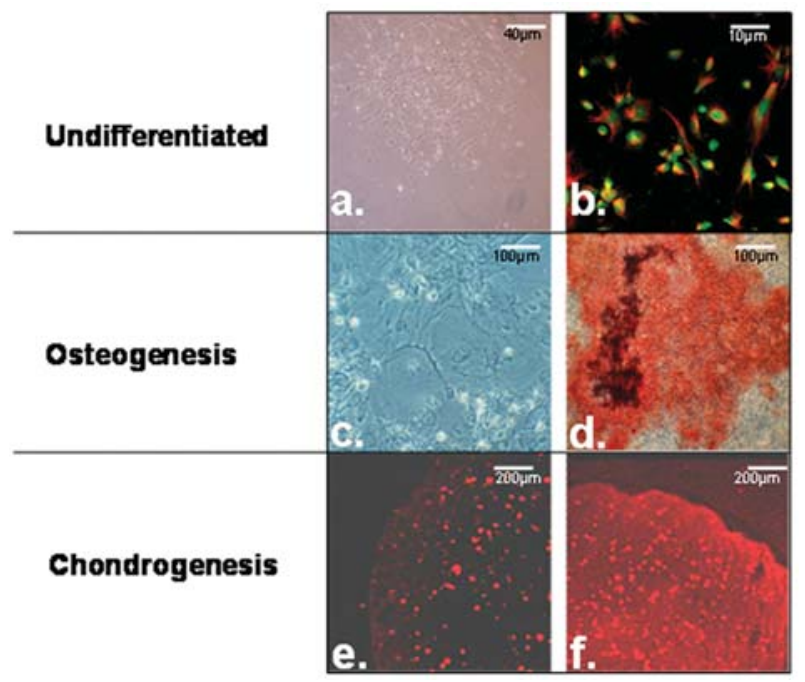

Figure 1. Morphological characterisation of MPCs. CFU-F like marrow derived adherent cells (a) characterized by double-immunofluorescence staining with D7fib (red fluorescence) and CD49a (green fluorescence) (b) exhibited typical stem cell morphology. At day 21 after induction of osteogenic differentiation in monolayer the cells were stained with alizarin red. Positive staining indicates calcified matrix formation (d) while the control culture kept in proliferation medium remained unstained (c). Chondrogenically differentiated cells kept in alginate beads were stained with an antibody against collagen II. After 21 days in 3D-culture the extracellular matrix displayed a positive collagen II signal in the cell surrounding newly synthesized matrix (f) which was undetectable at day 0 of 3D-culture (e)

of cell culture supernatant or cell lysates containing $100 \mu \mathrm{g}$ of total protein. Both, cell culture supernatant and cell lysates were harvested at the endpoint (21 days) of culture duration. Cell lysates were prepared by using cell lysis buffer provided by the manufacturer. After washing and incubation with biotin coupled anti-cytokine antibodies for $2 \mathrm{~h}$ a second series of washing was performed and then the membranes were incubated with horseradish peroxidase-conjugated streptavidin for $2 \mathrm{~h}$. Signals were detected with the provided detection solution using a CURIX 60 film developer (Agfa, Germany).

Statistics. Changes in gene expression $<2$-fold were not considered physiologically relevant and therefore described as unchanged $(27,28)$ even if statistically significant. Expression rates of genes were compared between the two groups (undifferentiated and differentiated) using onerepeated measure ANOVA with the assumption of homogeneity of variance used as appropriate. Only where a statistical significance was found, pair-wise comparisons of the groups were performed using the t-test. A p-value $<0.05$ was considered statistically significant.

\section{Results}

Cellular morphology and surface antigen marker profile of MPCs. Formation of CFU-F is one of the basic classifications of bone marrow derived stem cells along with rapid adhesion and extended proliferation capacity (29). After in vitro expansion of bone marrow isolated cells, colony forming units of fibroblast like cells (CFU-F) designated as MPCs readily adhered to the culture flasks and showed typical fibroblast-

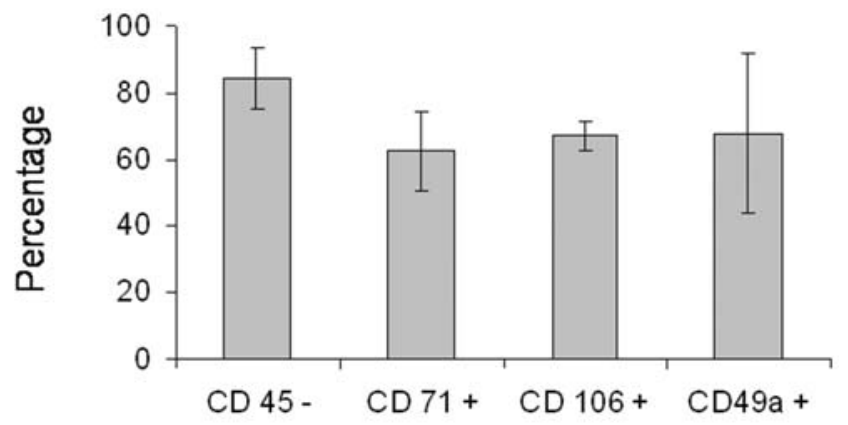

Figure 2. Antigen profiling of MPCs. Separation of bone marrow-derived adherent cells by magnetic antibody labelling resulted in a mixture of 60 75\% CD71-, CD49a- and CD106-positive cells. About $85 \%$ of the cells were CD45-negative stromal cells indicating a slightly heterogeneous population with $\sim 15 \%$ of CD45-positive haematopoietic cells. $n=3-5$ independent experiments.

like morphology (Fig. 1a). Immunofluorescence analysis of the adherent cells exhibited positive staining for fibroblast marker D7fib which is described as a specific marker for MPCs as suitable as STRO-1 and CD105 (30). Positive staining was also detected for $\alpha 1$ integrin marker CD49a (Fig. 1b). To confirm that isolated cells are indeed MPCs, cells were tested for their retained differentiation potential after expansion in vitro. MPCs were induced for up to 21 days in monolayer culture to undergo osteogenesis and, in 3-D high density alginate cultures for chondrogenesis. Osteogenic cultures stained positive for alizarin red indicating formation of a calcified matrix while uninduced control cultures remained unstained (Fig. 1c and d). Chondrogenically induced cells exhibited extensive collagen II staining in the surrounding matrix on day 21 of the culture which was undetectable at day 0 (Fig. 1e and f).

Since a unique MPC marker is not yet identified, culture purity is usually determined by employing a consortium of positive and negative markers. In this study adherent cells were screened by magnetic cells sorting (MACS ${ }^{\mathrm{TM}}$ ) using the three MPC-positive markers CD71 (transferrin receptor) (31), CD106 (VCAM) (32) and CD49a (integrin subunit $\alpha 1)(33,34)$ (Fig. 2). These markers reveal $60-65 \%$ of the cells as CD71 positive and $75 \%$ positive for CD106 and CD49a. In addition, CD45 (leukocyte common antigen) $(35,36)$, a haematopoietic surface marker used for negative selection, revealed strong enrichment of MPCs with a remaining $15 \%$ of CD45-positive cells.

Gene expression profiling of undifferentiated and differentiated MPCs. With the help of quantitative RT-PCR and specific primers (Table I) mRNA expression of selected genes was determined in un-induced, undifferentiated MPCs (day 0) and defined as baseline or calibrator gene expression (data not shown).

After application of osteogenic or chondrogenic favourable conditions to the cell cultures for up to 21 days, relative changes in mRNA level were determined on days 7, 14 and 21 (Fig. 3A-H). During induction of chondrogenic differentiation, tissue inhibitor of matrix metalloproteases (TIMP-1) became downregulated at day 21 while TIMP-2, MMP-2 and -13 remained upregulated until day 21 (Fig. 3A). Integrin subunit $\alpha 11$ was upregulated non-physiologically (2x) according to 
A

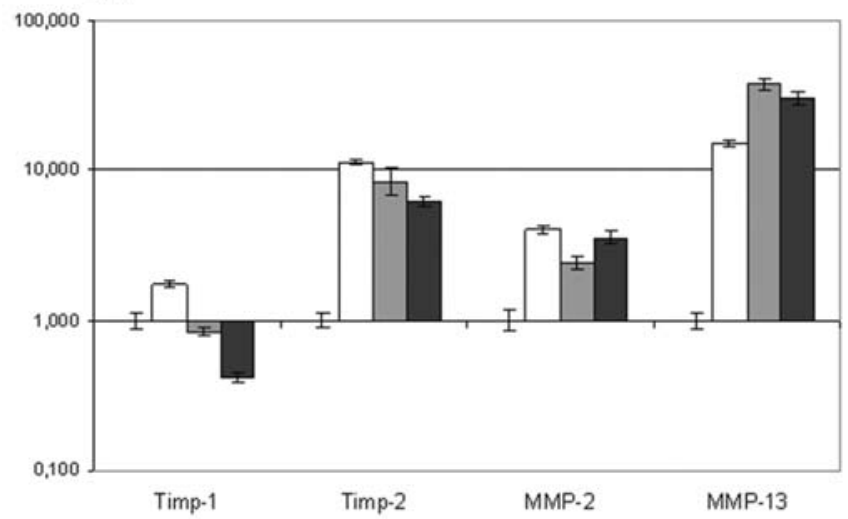

B

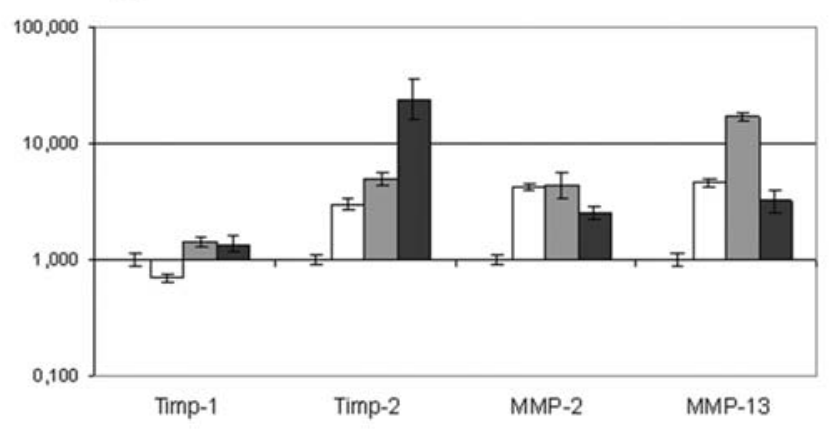

E
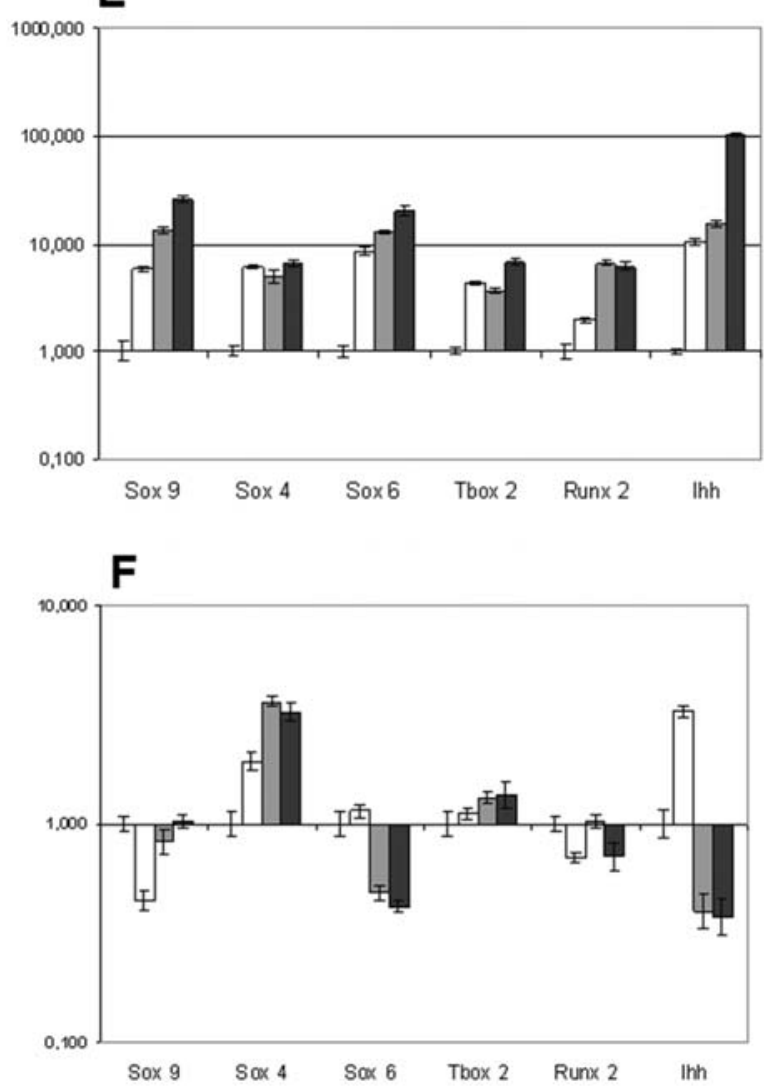

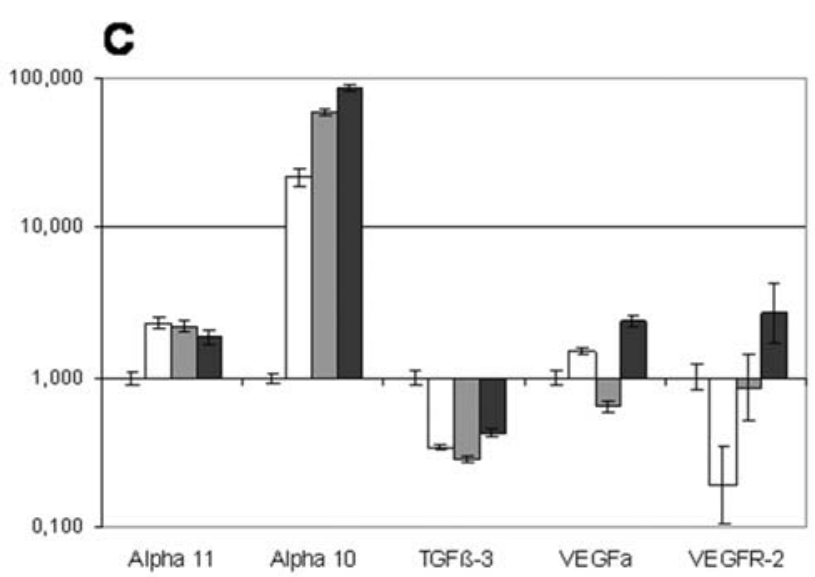

D

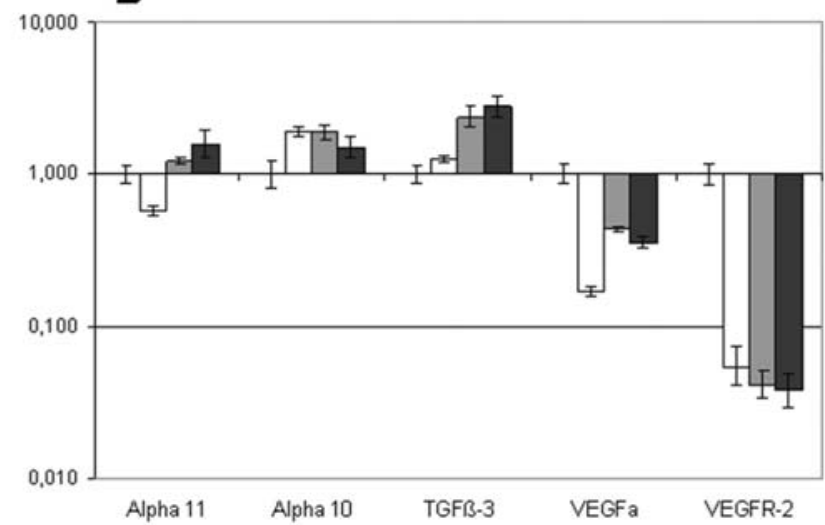

$\mathbf{G}$

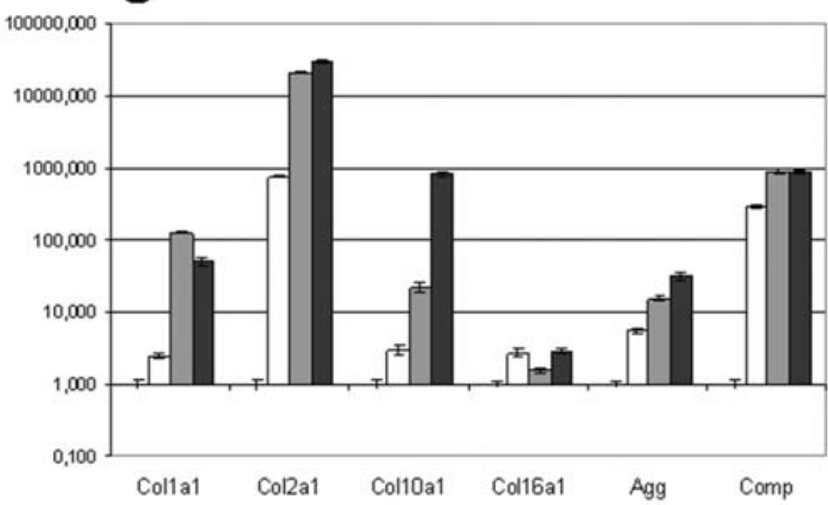

H

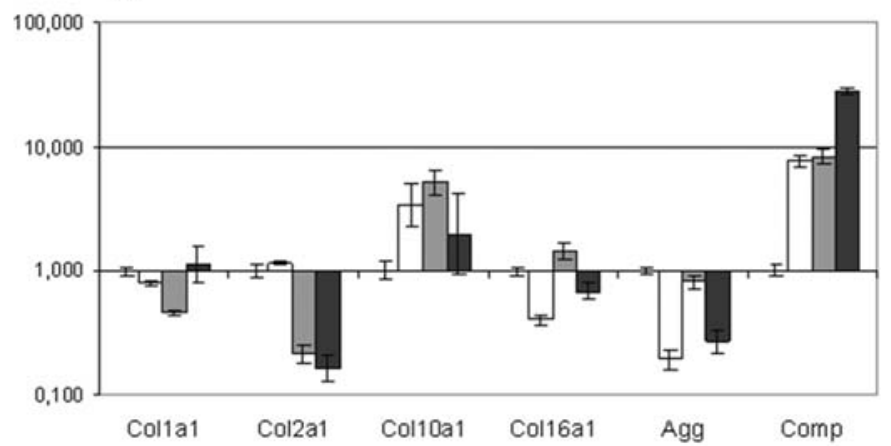

Figure 3. Differential gene expression profile of MPCs during osteo-chondrogenic differentiation. Relative quantitative mRNA expression level (RQ) of selected TIMPs, MMPs, Integrin subunits, collagens, transcription factors and growth factors was determined by the $\Delta \Delta C \mathrm{~T}$ method using $\beta$-actin gene expression as endogenous control and gene expression of undifferentiated MPCs as calibrator which was set at 1 . Expression level of each gene was determined at day 7 (white bars), day 14 (grey bars) and day 21 (black bars) during chondrogenic (A, C, E, G) and osteogenic (B, D, F, H) differentiation of MPCs. $\mathrm{n}=4-7$ independent experiments. 
Table II. Regulation of gene expression during osteo-chondrogenic differentiation of MPCs at day 21 (end point of culture regimen) expressed as relative quantification values (RQ).

\begin{tabular}{|c|c|c|c|}
\hline Gene & RQ chondrogenesis & RQ osteogenesis & $\begin{array}{c}\text { Ratio RQ of } \\
\text { chondrogenesis/osteogenesis }\end{array}$ \\
\hline Col2a1 & $30818.00^{* * *}$ & $0.20^{* * *}$ & 181276.00 \\
\hline Col10a1 & $808.00^{* * *}$ & 2.00 n.s. & 404.00 \\
\hline Ihh & $103.00^{* * *}$ & $0.40^{* * *}$ & 274.00 \\
\hline Aggrecan & $32.00^{* * * *}$ & $0.30^{* * *}$ & 107.00 \\
\hline VEGFR-2 & $2.70^{* *}$ & $0.04^{* * *}$ & 67.50 \\
\hline Integrin $\alpha 10$ & $85.00^{* * *}$ & $1.50^{* * *}$ & 57.00 \\
\hline Sox6 & $20.50^{* * *}$ & $0.40^{* * *}$ & 51.00 \\
\hline Colla1 & $50.00^{* * *}$ & 1.00 n.s. & 50.00 \\
\hline COMP & $897.00^{* * *}$ & $28.00^{* * *}$ & 32.00 \\
\hline Sox 9 & $26.00^{* * *}$ & 1.00 n.s. & 26.00 \\
\hline CINC-2 & $1.50^{* * *}$ & $0.15^{* * *}$ & 10.00 \\
\hline MMP-13 & $30.00^{* * *}$ & $3.00^{* * *}$ & 10.00 \\
\hline Runx2 & $6.00^{* * *}$ & $0.70^{*}$ & 8.60 \\
\hline VEGF $\alpha$ & $2.40^{* * *}$ & $0.35^{* * *}$ & 6.90 \\
\hline Tbox 2 & $6.70^{* * * *}$ & $1.35^{* * *}$ & 5.00 \\
\hline Col16a1 & $2.80^{* * * *}$ & $0.70^{* * * *}$ & 4.00 \\
\hline Sox 4 & $6.50^{* * *}$ & $3.25^{* * *}$ & 2.00 \\
\hline MMP-2 & $3.60^{* * *}$ & $2.50^{* * *}$ & 1.40 \\
\hline Integrin $\alpha 11$ & $2.00^{* * * *}$ & $1.60^{* * * *}$ & 1.25 \\
\hline TIMP-2 & $6.20^{* * *}$ & $23.60^{* * *}$ & 0.30 \\
\hline TIMP-1 & $0.40^{* * *}$ & $1.40^{*}$ & 0.30 \\
\hline$ß-\mathrm{NGF}$ & $0.20^{* * * *}$ & $0.60^{* * * *}$ & 0.30 \\
\hline TGFß-3 & $0.40^{* * * *}$ & $2.80^{* * * *}$ & 0.14 \\
\hline MCP-1 & $0.05^{* * *}$ & 1.00 n.s. & 0.05 \\
\hline
\end{tabular}

Values $>1$ indicate upregulation, values $<1$ indicate downregulation of the gene relative to the calibrator (undifferentiated MPCs set as 1). ${ }^{*} \mathrm{p}<0.05 ;{ }^{* *} \mathrm{p}<0.01 ;{ }^{* * *} \mathrm{p}<0.001 ;$ n.s., non-significant.

Pfaffl $(27,28)$ while integrin subunit $\alpha 10$ became strongly induced. Gene expression of TGFß-3 was downregulated from day 7 while vascular endothelial growth factor (VEGF) $\alpha$ and VEGFR-2 mRNA level were moderately increased at the end of culture time after an earlier suppression (Fig. 3C). Gene expression of transcription factors Sox9, Sox6, Sox4, Tbox2, Runx2 and Ihh was clearly upregulated with an increase towards the culture end point (Fig. 3E). Notably, Ihh mRNA level increased up to $100 \mathrm{x}$ at day 21 . All collagens were upregulated during culture time with a profound increase in gene expression for Col2a1 $(>30,000 \mathrm{x})$ and the lowest change for Col16a1 (2.8x). Gene expression of aggrecan and COMP was strongly induced over culture time (Fig. 3G).

Induction of osteogenic differentiation resulted in a mostly altered expression profile of these genes. TIMP-1 was not regulated in physiologically relevant terms $(<2 \mathrm{x})$ while gene expression of TIMP-2 was more profoundly upregulated at day 21 than in chondrogenic differentiation (23x versus $6 x)$. MMP-2 gene expression was similarly regulated as under chondrogenic differentiation while MMP-13 became downregulated at the end of culture compared to chondrogenic conditions (3x versus 30x) (Fig. 3B). During osteogenic differentiation changes in expression for integrin subunits $\alpha 10$ and $\alpha 11$ remained below physiological relevance. Contrary to chondrogenesis TGFß-3 mRNA level was moderately upregulated during osteogenic culture time $(2.8 \mathrm{x})$ while both VEGF $\alpha$ and VEGFR-2 mRNAs were downregulated, gene expression of VEGFR-2 decreased $25 \mathrm{x}$ compared to its expression in undifferentiated MPCs (Fig. 3D). Gene expression profiles of all transcription factors (except for Sox4) was different under osteogenic compared to chondrogenic culture conditions. Sox 9 was downregulated at day 7 while at the end of culture time gene expression was similar to undifferentiated MPCs. Sox6 and Ihh mRNA level were strongly suppressed towards later time points while Tbox 2 remained unaltered and Runx2 was slightly downregulated (Fig. 3F). Also, collagen gene expression profiles were different from chondrogenic induced MPCs. During osteogenesis Colla1 mRNA level did not change compared to undifferentiated MPCs while Col2a1 was profoundly downregulated during progression of osteogenesis. Col10a1 was upregulated until day 14 and almost reduced to the level of uninduced MPCs at day 21. Gene expression of Col61a1 and aggrecan decreased over culture time while COMP became upregulated, however, less profoundly as under chondrogenic differentiation conditions (28x versus 900x) (Fig. 3H). Regulation data from the end 

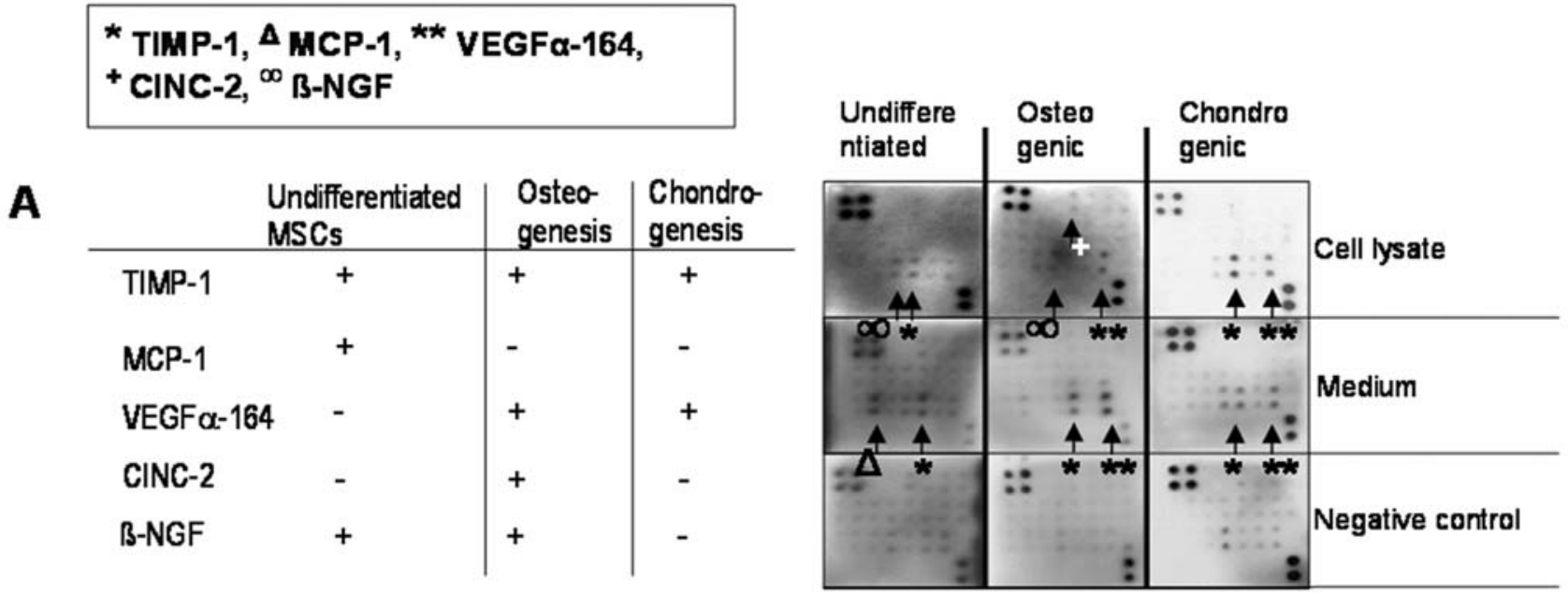

B

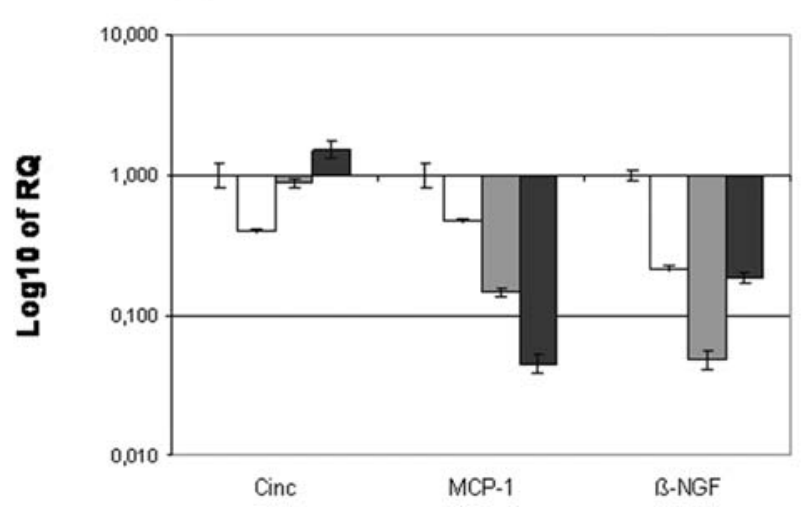

C

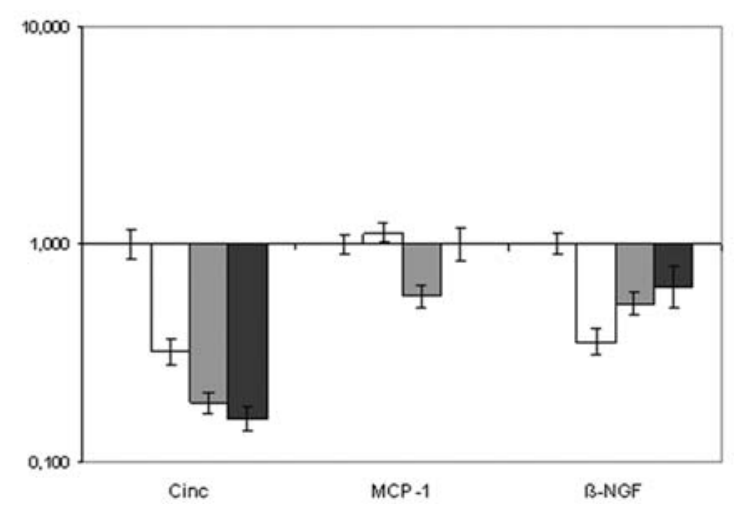

Figure 4. Comparison of cytokine and growth factor profiles of undifferentiated and differentiated MPCs. An antibody array containing 14 different cytokines plus TIMP-1, B-NGF, VEGF $\alpha-165$, leptin and CNTF was used to compare protein profiles of proliferated undifferentiated, uninduced MPCs and MPCs after osteogenic and chondrogenic induction (A). ${ }^{*} \mathrm{TIMP}-1,{ }^{* *} \mathrm{VEGF} \alpha-164, \Delta \mathrm{MCP}-1,{ }^{\infty} \mathrm{B}-\mathrm{NGF},{ }^{+} \mathrm{CINC}-2$. Representative blots of a total of 5 independent experiments are shown; $n=3$ for culture supernatants and $n=2$ for cell lysates. Temporal gene expression profiles of MCP-1, CINC-2 and 3 -NGF was determined by qRT-PCR as described above (B and C).

point of the different culture regimen (day 21) are displayed in Table II.

Cytokine and growth factor protein profile of undifferentiated and differentiated MPCs. Cell culture supernatants and lysates from undifferentiated and differentiated MPCs at day 21 were analyzed for secretory molecules using an antibody array covering 14 cytokines plus B-NGF, TIMP-1, CNTF, leptin and VEGF $\alpha$-164 (Fig. 4). TIMP-1 was the only molecule secreted from undifferentiated as well as differentiated MPCs, while the cytokine monocyte chemoattractant protein (MCP-1) was exclusively secreted from undifferentiated MPCs. Secretion of VEGF (variant VEGF $\alpha$-164) was observed only after induction of osteogenic and chondrogenic differentiation. When the same antibody array was examined with the cell lysate two additional molecules were identified. Nerve growth factor ( $ß-\mathrm{NGF}$ ) was detected in undifferentiated and osteogenically induced cells only and cytokine induced neutrophil chemoattractant (CINC-2) was detected as a weak spot after osteogenesis. Both factors were undetectable after chondrogenic induction (Fig. 4A). The remaining 14 proteins of the array were undetectable in all culture conditions analysed, these include, CINC-3, ciliary neurotrophic factor
(CNTF), fractalkine, GM-CSF, IFN- $\gamma$, IL-1 $\alpha,-1 \beta,-4,-6,-10$, lipopolysaccharide induced $\mathrm{c}-\mathrm{X}-\mathrm{c}$ chemokine (LIX), leptin, macrophage inflammatory protein (MIP- $3 \alpha$ ) and TNF- $\alpha$.

Gene expression level of MCP-1 was profoundly downregulated during chondrogenic differentiation while unchanged along osteogenic differentiation pathway expression. CINC-2 was downregulated upon osteogenic differentiation and remained unaltered during chondrogenic differentiation ( $<2 \mathrm{x}$ at day 21) while gene expression of $\mathrm{B}-\mathrm{NGF}$ was decreased upon induction of MPC differentiation (Fig. 4B and C).

$R Q$ values and ratios. Table II summarizes regulation of gene expression at the end point of the osteo-chondrogenic differentiation culture regimens (day 21). Opposite regulated genes include Col2a1, Ihh, aggrecan, VEGFR-2, Sox6, Runx 2, VEGF $\alpha$, Col16a1 and TGFß-3. Except for TGFß-3, the other genes listed above were downregulated upon induction of osteogenesis and upregulated upon chondrogenesis. Genes that are not regulated upon osteogenesis but upregulated upon chondrogenesis were Col10a1, integrin subunit $\alpha 10$, Col1a1, Sox9, Tbox2, integrin subunit $\alpha 11$ while TIMP-1 and MCP-1 were downregulated upon chondrogenesis. Only CINC-2 mRNA level was suppressed in osteogenesis and 
remained unchanged upon chondrogenesis. Genes upregulated under both osteogenic and chondrogenic differentiation conditions include COMP, MMP-13, Sox4, MMP-2 and TIMP-2. The only gene downregulated under both differentiation pathways was $\mathrm{B}-\mathrm{NGF}$.

The ratio of RQ reflects whether the gene is up- or downregulated in chondrogenesis versus osteogenesis. Values $>1$ indicate upregulation of mRNA levels during chondrogenesis while values $<1$ indicate downregulation during chondrogenesis compared to osteogenesis.

\section{Discussion}

Rat is an appropriate animal model for MPC based pre-clinical studies due to high reproducibility and at the same time provides a sufficient number of bone marrow derived cells. However, a representative gene expression profile of rat naïve and differentiated MPCs is not available and as the expression of known genes is not identical to adult human stem cells, a comprehensive profiling of rat gene and protein expression is necessary for accurate interpretation of data generated with rat MPCs.

Here, we present a time course profiling of a selected panel of genes mostly differentially regulated in undifferentiated and osteo-chondrogenically differentiated rat MPCs. These genes include growth factors, transcription factors, metalloproteinases (MMPs) and their inhibitors (TIMPs), structural components of the matrix and cell adhesion molecules. Several of these genes routinely serve as markers to determine osteo-chondrogenic differentiation status of human chondrocytes, osteocytes and MPCs (col1a1, col2a1, col10a1, Runx2, Sox9, aggrecan) others are not yet implicated in osteo-chondrogenic differentiation of MPCs (Col16a1, Sox4, TIMP1, -2, MCP-1, ß-NGF and CINC-2). Not much is known about the temporal involvement of all of these markers in osteo-chondrogenic differentiation processes of rat MPCs and whether their regulation is comparable to the human system.

Identification of genomic marker for monitoring osteogenesis and chondrogenesis. Integrin subunit $\alpha 11$, expressed in undifferentiated rat MPCs, is present in various mesenchymal tissues around the cartilage anlage in the developing skeleton. In comparison, integrin subunit $\alpha 10$, known as a highly chondrocyte specific, collagen II and IX-binding integrin $(37,38)$, was not detected in naïve MPCs. Chondrogenic differentiation of MPCs leads to 85 -fold increase in the mRNA level of $\alpha 10$, whereas the $\alpha 11$ mRNA level remains mostly unchanged. Gene expression profile of both integrin subunits remained unaltered during the osteogenic differentiation pathway. Thus, the ratio of $\alpha 11 / \alpha 10$ gene expression is highly appropriate for monitoring the progression of chondrogenic versus osteogenic differentiation of MPCs.

Gene expression profiles of growth factors TGFß-3 and VEGF $\alpha$, including its receptor VEGFR-2, are differentially regulated upon induction of osteo-chondrogenically differentiation.

During endochondral bone formation angiogenic factor VEGF modulates matrix mineralization in hypertrophic cartilage in an autocrine manner by upregulating the expression of its receptor (39). Here, VEGF $\alpha$ and VEGFR-2 gene expression levels become induced in MPCs after entering the chondrogenic pathway while commitment to osteogenic differentiation regimen results in strong downregulation of VEGF $\alpha$ and VEGFR-2 mRNA. Hence, comparison of relative VEGF $\alpha$ and VEGFR-2 mRNA levels are useful indicators of MPC differentiation stage and lineage commitment.

Transcription factors which regulate osteo- and chondrogenic lineage commitment as, Tbox 2 (brachyury), Sox9, Sox6 and Runx 2 are clearly upregulated during chondrogenic differentiation. Both, Sox 9 and Tbox 2 are essential components for the BMP-dependent onset of chondrogenesis (40). Except for Sox 4, the other four transcription factors were differentially regulated under osteogenic culture conditions. Differential expression levels of these transcription factors might serve as markers for harvesting osteo-chondroprogenitor cells at different stages of lineage commitment thus allowing reproducible separation and identification of these early committed cells. Similarly, Sox4 was not implicated in being involved in the osteogenic differentiation pathway and not much is known regarding its involvement in chondrogenic differentiation except that Sox 4 and BMP-2, together with collagens I and IV are upregulated in early chondrogenic differentiating human MPCs kept in alginate beads (41). During chondrogenic differentiation, gene expression of both Sox 9 and Ihh is strongly induced, indicating cellular arrest in the early hypertrophic stage. Sox 9 is expressed in all essential stages of chondrogenic development, but its expression is abrogated in hypertrophic chondrocytes $(42,43)$ which may be regulated by a negative feedback mechanism of the PTHrP and Ihh signal cascade in pre-hypertrophic chondrocytes $(44,45)$. However, this expression profile is accompanied by strong upregulation of collagen $\mathrm{X}$ gene expression which is restricted to terminally differentiated hypertrophic chondrocytes (46). Possibly, upregulation of collagen X is connected to increased expression of Runx 2 since multiple Runx2 consensus binding elements are located in the collagen $\mathrm{X}$ promoter region (47). However, collagen $\mathrm{X}$ expression in vitro is not in line with the expression of other differentiation markers. This limitation in using collagen $\mathrm{X}$ as a marker for chondrogenesis of human MPCs is described in previous literature $(48,49)$. Our data suggest the same for rat MPCs during chondrogenic differentiation.

MMPs alter the activity or function of numerous proteins by proteolytic processing and they are also involved in various cellular functions and matrix formation during development. Expression of MMPs and TIMPs in MPC cultures was reported on in earlier studies on human MPCs of different origins $(50,51)$. MMP-13 together with its inhibitors, TIMP-1 and -2 is expressed in MPCs indicating a role in stem cell migration and proliferation as it is assigned to MMP-2 (52). While TIMP-1 gene expression remains mainly unaltered or is downregulated, MMP-13 and TIMP-2 were upregulated during both, chondrogenic and osteogenic culture regimen. A relatively higher MMP-13 mRNA level during chondrogenesis might obtain relevance in progressing mineralization as MMP-13 is involved in endochondral and intramembranous ossification (53).

We report, for the first time, on gene expression of collagen XVI in undifferentiated MPCs which is upregulated during chondrogenesis while downregulated during osteo- 
genesis. This observation indicates an unknown role of this fibril-associated collagen with interrupted triple helices (FACIT) in proliferation of un-induced MPCs and/or chondrogenic differentiation. As known for human MPCs, collagen II and aggrecan gene expression are upregulated during chondrogenesis and reduced in osteogenesis, therefore their differential expression profiles obtained in this study are also usable for rat MPCs as marker of chondrogenic commitment.

Identification of proteomic marker for monitoring osteogenesis and chondrogenesis. Secretory cytokines, proteases and growth factors are key players in cell proliferation and differentiation. Therefore, we investigated MPC differentiation state-specific protein profile. TIMP-1, the only identified molecule secreted from undifferentiated as well as differentiated MPCs is a multifunctional molecule. In addition to its physiological activity as inhibitor of MMPs, it is also thought to be involved in regulation of cell growth and differentiation of a variety of cell types including mesenchymal and epithelial cells (54). Hence, TIMP-1 secreted differentiation independently of MPCs act either as a growth factor or as an inducer/repressor of specific factors necessary for commitment to the osteo-chondrogenic lineage of MPCs.

MCP-1, which recruits monocytes into ischemic tissue and stimulates chemotaxis, is secreted exclusively from uninduced MPCs while its gene expression remains unchanged or is repressed during osteo-chondrogenic differentiation, respectively. It is speculated to be involved in homing of circulating stem and progenitor cells. MPCs secrete this chemokine to the region of injuries which contribute to healing processes $(55,56)$. MCP- 1 secretion appears suitable as a marker for un-induced rat MPCs not having entered the chondrogenic and osteogenic differentiation cascade.

Secretion of the rat-specific splice variant of VEGF, VEGF $\alpha-164$, was induced only after cells were subjected to osteogenic and chondrogenic differentiation. VEGF as a multifaceted protein has a role in induction of metalloproteinases, such as MMP-13 during the late stages of chondrogenesis marking the onset of hypertrophy (57). Lack of VEGF secretion in undifferentiated MPCs are taken as an indicator for a relatively pure MPC population, mostly devoid of VEGF secreting haematopoietic and endothelial progenitor cells $(58,59)$.

Analysis of the cellular lysates leads to the identification of two additional molecules. B-NGF, detected in undifferentiated as well as in cells after osteogenic induction and cytokineinduced neutrophil chemoattractant (CINC-2), which was detected after osteogenesis only. CINC-2 attracts neutrophils and was suggested to inhibit acute inflammation indicating an anti-inflammatory role in osteogenesis (60). So far, this chemokine has not been determined in rat MPCs undergoing osteogenic differentiation, however, our data suggest that CINC-2 is suitable as one of several reliable protein indicators for successfully induced osteogenesis in MPCs.

Undifferentiated, non-committed bone marrow derived cells are known to express $B-\mathrm{NGF}$ and its receptor (61) together with other neurotrophic factors (62). This falls in line with the observed production of $\mathrm{B}-\mathrm{NGF}$ in undifferentiated MPCs The naïve MPCs loose B-NGF biosynthesis upon chondro- genic differentiation but keep it under osteogenic favourable conditions which suggests a role of $\beta-N G F$ in osteogenesis as a trophic factor known to stimulate collagen synthesis and expression of specific osteogenic marker, such as alkaline phosphatase (63).

The discrepancy in reduced gene expression and protein synthesis/secretion profile of VEGF $\alpha, B-N G F$ and CINC-2 after differentiation is likely due to post-translational regulation. VEGF production is known to be regulated at the translational level as over-expression of transcription factor c-Myc related with rapid induction of tumors, also leads to 10-fold higher VEGF production while the gene expression level remains unaltered. The mechanisms of action are most likely higher ribosome biogenesis rates which increase translation efficiency of selected mRNAs (64). Also, in rat smooth muscle cells regulation of NGF production does not solely occur at the level of transcription. Post-transcriptional mechanisms, such as increased NGF mRNA stability and elevated synthesis of NGF protein per unit NGF mRNA, can operate $(65,66)$.

In conclusion, we demonstrated a specific gene and protein expression/secretion profile of rat $\mathrm{CD} 45^{\text {-low }}$ bone marrowderived progenitor cells. The defined single genes and gene combinations are considered suitable as markers allowing reliable and reproducible discrimination between the uninduced MPCs and the osteogenically and chondrogenically differentiating MPCs (Table II). Discrimination is carried out also at protein level with the help of the two cytokines MCP-1 and CINC-2 indicative for un-induced and osteogenically differentiated MPCs, respectively. The knowledge of differentially expressed genes and proteins provides a foundation for optimizing cell culture conditions necessary to properly induce and maintain desired differentiation pathways. This is a prerequisite for not only manipulating MPCs in animal models to regenerate complex tissues such as cartilage and bone but also for future tissue engineering studies with human adult MPCs.

\section{Acknowledgements}

We thank Dr Evy Lundgren-Akerlund (Cartella AG, Sweden) for providing $\alpha 10$ and $\alpha 11$ primers. We also thank Maren Marschner for her excellent technical support. This work was supported by a DFG grant assigned to SG (GR 1301/7-1).

\section{References}

1. Cancedda R, Dozin B, Giannoni P and Quarto R: Tissue engineering and cell therapy of cartilage and bone. Matrix Biol 22: 81-91, 2003.

2. Friedenstein AJ, Gorskaja JF and Kulagina NN: Fibroblast precursors in normal and irradiated mouse hematopoietic organs. Exp Hematol 4: 267-274, 1976.

3. Bruder SP, Fink DJ and Caplan AI: Mesenchymal stem cells in bone development, bone repair, and skeletal regeneration therapy. J Cell Biochem 56: 283-294, 1994.

4. Quarto R, Mastrogiacomo M, Cancedda R, Kutepov SM, Mukhachev V, Lavroukov A, Kon E and Marcacci M: Repair of large bone defects with the use of autologous bone marrow stromal cells. N Engl J Med 344: 385-386, 2001

5. Horwitz EM, Prockop DJ, Fitzpatrick LA, Koo WW, Gordon PL, Neel M, Sussman M, Orchard P, Marx JC, Pyeritz RE and Brenner MK: Transplantability and therapeutic effects of bone marrow-derived mesenchymal cells in children with osteogenesis imperfecta. Nat Med 5: 309-313, 1999. 
6. Mao JJ: Stem-cell-driven regeneration of synovial joints. Biol Cell 97: 289-301, 2005.

7. Raghunath J, Salacinski HJ, Sales KM, Butler PE and Seifalian AM: Advancing cartilage tissue engineering: the application of stem cell technology. Curr Opin Biotechnol 16: 503-509, 2005

8. Wakitani S, Imoto K, Yamamoto T, Saito M, Murata N and Yoneda M: Human autologous culture expanded bone marrow mesenchymal cell transplantation for repair of cartilage defects in osteoarthritic knees. Osteoarthritis Cartilage 10: 199-206, 2002.

9. Litzke LE, Wagner E, Baumgaertner W, Hetzel U, Josimovic-Alasevic $\mathrm{O}$ and Libera J: Repair of extensive articular cartilage defects in horses by autologous chondrocyte transplantation. Ann Biomed Eng 32: 57-69, 2004.

10. Wilke MM, Nydam DV and Nixon AJ: Enhanced early chondrogenesis in articular defects following arthroscopic mesenchymal stem cell implantation in an equine model. J Orthop Res 25: 913-925, 2007.

11. Wagner W, Wein F, Seckinger A, Frankhauser M, Wirkner U, Krause U, Blake J, Schwager C, Eckstein V, Ansorge W and Ho AD: Comparative characteristics of mesenchymal stem cells from human bone marrow, adipose tissue, and umbilical cord blood. Exp Hematol 33: 1402-1416, 2005.

12. Gerstenfeld LC, Cullinane DM, Barnes GL, Graves DT and Einhorn TA: Fracture healing as a post-natal developmental process: molecular, spatial, and temporal aspects of its regulation. J Cell Biochem 88: 873-884, 2003.

13. Tsuchida H, Hashimoto J, Crawford E, Manske P and Lou J Engineered allogeneic mesenchymal stem cells repair femoral segmental defect in rats. J Orthop Res 21: 44-53, 2003

14. Gysin R, Wergedal JE, Sheng MH, Kasukawa Y, Miyakoshi N, Chen ST, Peng H, Lau KH, Mohan S and Baylink DJ: Ex vivo gene therapy with stromal cells transduced with a retroviral vector containing the BMP4 gene completely heals critical size calvarial defect in rats. Gene Ther 9: 991-999, 2002.

15. Yamazaki M, Nakajima F, Ogasawara A, Moriya H, Majeska RJ and Einhorn TA: Spatial and temporal distribution of CD44 and osteopontin in fracture callus. J Bone Joint Surg Br 81: 508-515, 1999.

16. Asahina I, Sampath TK, Nishimura I and Hauschka PV: Human osteogenic protein-1 induces both chondroblastic and osteoblastic differentiation of osteoprogenitor cells derived from newborn rat calvaria. J Cell Biol 123: 921-933, 1993.

17. Jackson RA, McDonald MM, Nurcombe V, Little DG and Cool SM: The use of heparan sulfate to augment fracture repair in a rat fracture model. J Orthop Res 24: 636-644, 2006.

18. Li J, Ahmad T, Bergstrom J, Samnegard E, Erlandsson-Harris H, Ahmed $\mathrm{M}$ and Kreicbergs A: Differential bone turnover in an angulated fracture model in the rat. Calcif Tissue Int 75: 50-59, 2004

19. Yanada S, Ochi M, Adachi N, Nobuto H, Agung M and Kawamata S: Effects of CD44 antibody- or RGDS peptide-immobilized magnetic beads on cell proliferation and chondrogenesis of mesenchymal stem cells. J Biomed Mater Res A 77: 773-784, 2006.

20. Bruder SP, Jaiswal N, Ricalton NS, Mosca JD, Kraus KH and Kadiyala S: Mesenchymal stem cells in osteobiology and applied bone regeneration. Clin Orthop Relat Res 355: S247-S256, 1998.

21. Ju YJ, Muneta T, Yoshimura H, Koga H and Sekiya I: Synovial mesenchymal stem cells accelerate early remodeling of tendonbone healing. Cell Tissue Res 332: 469-478, 2008.

22. Hadjiargyrou M, Lombardo F, Zhao S, Ahrens W, Joo J, Ahn H, Jurman M, White DW and Rubin CT: Transcriptional profiling of bone regeneration. Insight into the molecular complexity of wound repair. J Biol Chem 277: 30177-30182, 2002.

23. Ahmed N, Vogel B, Rohde E, Strunk D, Grifka J, Schulz MB and Grassel S: CD45-positive cells of haematopoietic origin enhance chondrogenic marker gene expression in rat marrow stromal cells. Int J Mol Med 18: 233-240, 2006

24. Johnstone B, Hering TM, Caplan AI, Goldberg VM and Yoo JU: In vitro chondrogenesis of bone marrow-derived mesenchymal progenitor cells. Exp Cell Res 238: 265-272, 1998.

25. Hauselmann HJ, Fernandes RJ, Mok SS, Schmid TM, Block JA Aydelotte MB, Kuettner KE and Thonar EJ: Phenotypic stability of bovine articular chondrocytes after long-term culture in alginate beads. J Cell Sci 107: 17-27, 1994.

26. Ginzinger DG: Gene quantification using real-time quantitative PCR: an emerging technology hits the mainstream. Exp Hematol 30: 503-512, 2002

27. Pfaffl MW: A new mathematical model for relative quantification in real-time RT-PCR. Nucleic Acids Res 29: e45, 2001
28. Bustin SA, Benes V, Nolan T and Pfaffl MW: Quantitative realtime RT-PCR-a perspective. J Mol Endocrinol 34: 597-601, 2005.

29. Bianco P, Riminucci M, Gronthos S and Robey PG: Bone marrow stromal stem cells: nature, biology, and potential applications. Stem Cells 19: 180-192, 2001.

30. Jones EA, Kinsey SE, English A, Jones RA, Straszynski L, Meredith DM, Markham AF, Jack A, Emery P and McGonagle D: Isolation and characterization of bone marrow multipotential mesenchymal progenitor cells. Arthritis Rheum 46: 3349-3360, 2002.

31. Jefferies WA, Brandon MR, Williams AF and Hunt SV: Analysis of lymphopoietic stem cells with a monoclonal antibody to the rat transferrin receptor. Immunology 54: 333-341, 1985

32. Buravkova LB and Anokhina EB: Effect of hypoxia on stromal precursors from rat bone marrow at the early stage of culturing. Bull Exp Biol Med 143: 411-413, 2007

33. Deschaseaux F, Gindraux F, Saadi R, Obert L, Chalmers D and Herve P: Direct selection of human bone marrow mesenchymal stem cells using an anti-CD49a antibody reveals their low phenotype. Br J Haematol 122: 506-517, 2003.

34. Gindraux F, Selmani Z, Obert L, Davani S, Tiberghien P, Herve $\mathrm{P}$ and Deschaseaux F: Human and rodent bone marrow mesenchymal stem cells that express primitive stem cell markers can be directly enriched by using the CD49a molecule. Cell Tissue Res 327: 471-483, 2007.

35. Woollett GR, Barclay AN, Puklavec M and Williams AF Molecular and antigenic heterogeneity of the rat leukocytecommon antigen from thymocytes and $\mathrm{T}$ and $\mathrm{B}$ lymphocytes. Eur J Immunol 15: 168-173, 1985.

36. Javazon EH, Colter DC, Schwarz EJ and Prockop DJ: Rat marrow stromal cells are more sensitive to plating density and expand more rapidly from single-cell-derived colonies than human marrow stromal cells. Stem Cells 19: 219-225, 2001.

37. Camper L, Hellman U and Lundgren-Akerlund E: Isolation, cloning, and sequence analysis of the integrin subunit alpha10, a beta1-associated collagen binding integrin expressed on chondrocytes. J Biol Chem 273: 20383-20389, 1998.

38. Camper L, Holmvall K, Wangnerud C, Aszodi A and Lundgren-Akerlund E: Distribution of the collagen-binding integrin alpha10beta1 during mouse development. Cell Tissue Res 306: 107-116, 2001

39. Mayer H, Bertram H, Lindenmaier W, Korff T, Weber H and Weich $\mathrm{H}$ : Vascular endothelial growth factor (VEGF-A) expression in human mesenchymal stem cells: autocrine and paracrine role on osteoblastic and endothelial differentiation. J Cell Biochem 95: 827-839, 2005.

40. Hoffmann A, Czichos S, Kaps C, Bachner D, Mayer H, Kurkalli BG, Zilberman Y, Turgeman G, Pelled G, Gross G and Gazit D: The T-box transcription factor Brachyury mediates cartilage development in mesenchymal stem cell line C3H10T1/2. J Cell Sci 115: 769-781, 2002.

41. Xu J, Wang W, Ludeman M, Cheng K, Hayami T, Lotz JC and Kapila S: Chondrogenic differentiation of human mesenchymal stem cells in three-dimensional alginate gels. Tissue Eng 14: 667-680, 2008

42. Zhao Q, Eberspaecher H, Lefebvre V and de Crombrugghe B: Parallel expression of Sox 9 and Col2a1 in cells undergoing chondrogenesis. Dev Dyn 209: 377-386, 1997.

43. Okubo Y and Reddi AH: Thyroxine downregulates Sox9 and promotes chondrocyte hypertrophy. Biochem Biophys Res Commun 306: 186-190, 2003.

44. Akiyama H, Chaboissier MC, Martin JF, Schedl A and de Crombrugghe B: The transcription factor Sox 9 has essential roles in successive steps of the chondrocyte differentiation pathway and is required for expression of Sox 5 and Sox6. Genes Dev 16: 2813-2828, 2002.

45. De Crombrugghe B, Lefebvre V, Behringer RR, Bi W Murakami S and Huang W: Transcriptional mechanisms of chondrocyte differentiation. Matrix Biol 19: 389-394, 2000.

46. Schmid TM, Popp RG and Linsenmayer TF: Hypertrophic cartilage matrix. Type X collagen, supramolecular assembly, and calcification. Ann NY Acad Sci 580: 64-73, 1990.

47. Zheng Q, Zhou G, Morello R, Chen Y, Garcia-Rojas X and Lee B: Type $\mathrm{X}$ collagen gene regulation by Runx 2 contributes directly to its hypertrophic chondrocyte-specific expression in vivo. J Cell Biol 162: 833-842, 2003.

48. Mwale F, Stachura D, Roughley P and Antoniou J: Limitations of using aggrecan and type $\mathrm{X}$ collagen as markers of chondrogenesis in mesenchymal stem cell differentiation. J Orthop Res 24: $1791-1798,2006$ 
49. Pelttari K, Steck E and Richter W: The use of mesenchymal stem cells for chondrogenesis. Injury 39: S58-S65, 2008.

50. Silva WA Jr, Covas DT, Panepucci RA, Proto-Siqueira R Siufi JL, Zanette DL, Santos AR and Zago MA: The profile of gene expression of human marrow mesenchymal stem cells. Stem Cells 21: 661-669, 2003.

51. Mannello F, Tonti GA, Bagnara GP and Papa S: Role and function of matrix metalloproteinases in the differentiation and biological characterization of mesenchymal stem cells. Stem Cells 86: 475-481, 2005.

52. Cronwright G, Le Blanc K, Gotherstrom C, Darcy P, Ehnman M and Brodin B: Cancer/testis antigen expression in human mesenchymal stem cells: down-regulation of SSX impairs cell migration and matrix metalloproteinase 2 expression. Cancer Res 65: 2207-2215, 2005

53. Tuckermann JP, Pittois K, Partridge NC, Merregaert J and Angel P: Collagenase-3 (MMP-13) and integral membrane protein $2 \mathrm{a}(\operatorname{Itm} 2 \mathrm{a})$ are marker genes of chondrogenic/ osteoblastic cells in bone formation: sequential temporal, and spatial expression of Itm2a, alkaline phosphatase, MMP-13, and osteocalcin in the mouse. J Bone Miner Res 15: 1257-1265, 2000.

54. Stetler-Stevenson WG and Seo DW: TIMP-2: an endogenous inhibitor of angiogenesis. Trends Mol Med 11: 97-103, 2005.

55. Kinnaird T, Stabile E, Burnett MS, Shou M, Lee CW, Barr S, Fuchs $\mathrm{S}$ and Epstein SE: Local delivery of marrow-derived stromal cells augments collateral perfusion through paracrine mechanisms. Circulation 109: 1543-1549, 2004

56. Liu $\mathrm{CH}$ and Hwang SM: Cytokine interactions in mesenchymal stem cells from cord blood. Cytokine 32: 270-279, 2005.

57. Pufe T, Harde V, Petersen W, Goldring MB, Tillmann B and Mentlein R: Vascular endothelial growth factor (VEGF) induces matrix metalloproteinase expression in immortalized chondrocytes. J Pathol 202: 367-374, 2004.

58. Rehman J, Li J, Orschell CM and March KL: Peripheral blood 'endothelial progenitor cells' are derived from monocyte/ macrophages and secrete angiogenic growth factors. Circulation 107: 1164-1169, 2003.
59. Iba O, Matsubara H, Nozawa Y, Fujiyama S, Amano K, Mori Y, Kojima $\mathrm{H}$ and Iwasaka T: Angiogenesis by implantation of peripheral blood mononuclear cells and platelets into ischemic limbs. Circulation 106: 2019-2025, 2002.

60. Nakagawa H, Komorita N, Shibata F, Ikesue A, Konishi K, Fujioka $\mathrm{M}$ and Kato $\mathrm{H}$ : Identification of cytokine-induced neutrophil chemoattractants (CINC), rat GRO/CINC-2 alpha and CINC-2 beta, produced by granulation tissue in culture: purification, complete amino acid sequences and characterization. Biochem J 301: 545-550, 1994.

61. Quirici N, Soligo D, Bossolasco P, Servida F, Lumini C and Deliliers GL: Isolation of bone marrow mesenchymal stem cells by anti-nerve growth factor receptor antibodies. Exp Hematol 30: 783-791, 2002.

62. Yaghoobi MM and Mowla SJ: Differential gene expression pattern of neurotrophins and their receptors during neuronal differentiation of rat bone marrow stromal cells. Neurosci Lett 397: 149-154, 2006

63. Yada M, Yamaguchi K and Tsuji T: NGF stimulates differentiation of osteoblastic MC3T3-E1 cells. Biochem Biophys Res Commun 205: 1187-1193, 1994.

64. Mezquita P, Parghi SS, Brandvold KA and Ruddell A: Myc regulates VEGF production in $\mathrm{B}$ cells by stimulating initiation of VEGF mRNA translation. Oncogene 24: 889-901, 2005.

65. Sherer TB, Neff PS and Tuttle JB: Increased nerve growth factor mRNA stability may underlie elevated nerve growth factor secretion from hypertensive vascular smooth muscle cells. Brain Res Mol Brain Res 62: 167-174, 1998

66. Sherer TB, Neff PS, Hankins GR and Tuttle JB: Mechanisms of increased NGF production in vascular smooth muscle of the spontaneously hypertensive rat. Exp Cell Res 241: 186-193, 1998. 